A N N A L E S

UNIVERSITATIS MARIAE CURIE-SKŁODOWSKA

LUBLIN - POLONIA

VOL. LXVII, 1

SECTIO G

2020

Uniwersytet Jana Kochanowskiego w Kielcach

GRZEGORZ SKOWRONEK

grzegorzs7@interia.pl

ORCID: 0000-0001-9800-8331

\title{
Finansowe aspekty prowadzenia działalności w zakresie zakładów wzajemnych
}

Financial Aspects of Operating in the Field of Mutual Bets

\section{WPROWADZENIE}

Poruszona w opracowaniu tematyka koncentruje się na określeniu warunków urządzania zakładów wzajemnych - regulacji, na podstawie których prowadzona jest działalność w tym zakresie oraz zasad opodatkowania zakładów podatkiem od gier hazardowych. Zwraca uwagę okoliczność, że ta niewątpliwie przynosząca zyski działalność jest jednocześnie poddana ścisłej reglamentacji w krajowym porządku prawnym. Powodem tych ograniczeń jest fakt, że zakłady wzajemne należą do gier hazardowych, a co za tym idzie łączą się z nimi zagrożenia, jakie niesie hazard, w tym w szczególności uzależnienie od gier. Odpowiedzią na niebezpieczeństwo uzależnienia jest wprowadzanie szeregu barier i restrykcji finansowych dla działalności związanej z organizowaniem zakładów wzajemnych. Jednocześnie należy zaznaczyć, że wprowadzenie reglamentacji jakiejkolwiek sfery działalności gospodarczej musi pozostawać w zgodzie z regulacjami Unii Europejskiej dotyczącymi swobód np. w zakresie przepływu usług. Istotne jest zatem, aby w toku niniejszych rozważań przeanalizować finansowe aspekty związane z zakładami wzajemnymi oraz poddać je ocenie z punktu widzenia wybranych standardów określonych przez orzecznictwo Trybunału Sprawiedliwości Unii Europejskiej (TSUE). 


\section{DEFINICJA ZAKŁADÓW WZAJEMNYCH}

Przepis art. 2 ustawy z dnia 19 listopada 2009 r. o grach hazardowych ${ }^{1}$ określa niezbędne cechy gier hazardowych, w tym zakładów wzajemnych. Należy więc przyjąć, że zakłady wzajemne zawierają się w ogólnej definicji gier hazardowych, ale mają też cechy własne. Warto zatem zacząć od wyjaśnienia pojęcia „hazard”.

Termin „hazard” pochodzi z języka arabskiego (az-zahr), w którym oznacza kostkę do gry lub grę w kości. W języku francuskim słowo ,hazard” oznacza przypadek, traf, ryzyko. W języku angielskim słowo gambling („hazard”) odnosiło się pierwotnie do nieuczciwej gry albo do oszukiwania w czasie jej trwania. Hazardzista był definiowany jako oszust, który zazwyczaj gra „na pieniądze” o przesadnie wysokie stawki. Obecnie powszechnie przyjmuje się, że hazard to uzyskiwanie pieniędzy czy innych nagród $\mathrm{w}$ grach z niepewnym wynikiem, opartych na przypadku losowym ${ }^{2}$. Z przypadkiem losowym łączy się ryzyko przegranej. W efekcie tego słowo „hazard” nierozerwalnie wiąże się z ryzykownym przedsięwzięciem, którego wynik zależy wyłącznie od przypadku. Najczęściej odnosi się do gry o pieniądze. Pojęcie to może również oznaczać 'ryzyko w grze, narażanie się na niebezpieczeństwo, ryzykowanie' ${ }^{3}$. Jeżeli to ryzyko prowadzone jest według pewnych zasad czy reguł, można wówczas mówić o ,grze hazardowej”.

Określenie „gra hazardowa” obejmuje swoim zakresem wszystkie gry, jeżeli wygrana lub przegrana uzależniona jest nie od umiejętności grających, lecz wyłącznie od losu. Cechą charakterystyczną, odróżniającą grę hazardową od niehazardowej, jest uzależnienie w grze hazardowej wygranej od tzw. wypadku losowego, który jest niezależny od uczestników gry. Natomiast wpłynięcie w jakikolwiek sposób na zmianę „wypadku losowego” przekreśla istotę hazardu4.

W grze hazardowej można zyskać lub stracić rzecz, przedmiot, pieniądze. Jest to gra o pieniądze lub o inne dobra rozumiane bardzo szeroko. Hazard wiąże się ze słowem „gra”, a zatem ukierunkowuje nas na działanie opisane według pewnych reguł, angażujące co najmniej dwóch lub więcej uczestników. Należy przy tym zaznaczyć, że stwierdzenie, iż gra hazardowa angażuje dwie strony, nie zawsze oznacza dwie osoby5.

Zgodnie z art. 2 ust. 1 u.g.h. grami losowymi są gry, w tym urządzane przez sieć Internet, o wygrane pieniężne lub rzeczowe, których wynik w szczególności zależy od przypadku. Odnosząc się do pozostałych zapisów art. 2 u.g.h., zauważyć

1 T.j. Dz.U. 2018, poz. 165 ze zm., dalej: u.g.h.

2 I. Niewiadomska, M. Brzezińska, B. Lelonek, Hazard, Lublin 2005, s. 11.

Słownik języka polskiego, red. M. Szymczak, t. 1, Warszawa 1982, s. 729.

4 M. Bojarski, W. Radecki, Kodeks wykroczeń. Komentarz, Warszawa 1998, s. 430; M. Bojarski, Glosa do uchwały SN z 16 lutego 1994 r., I KZP 39/94, „Wojskowy Przegląd Prawniczy” 1994, nr 3-4, s. 119.

5 B. Dzik, Hazard, [w:] Psychologia ekonomiczna, red. T. Tyszka, Gdańsk 2004, s. 567. 
należy, że przepis ten dokonuje szczegółowego wyliczenia i opisu gier losowych, zakładów wzajemnych, gier na automatach oraz gier w karty.

Zakłady wzajemne są zatem zaliczone do gier hazardowych jako jedna z kategorii gier, obok gier losowych, gier w karty i gier na automatach. Ustawa o grach hazardowych odróżnia dwa typy zakładów wzajemnych, tj. totalizatory i zakłady bukmacherskie. Totalizatory to zakłady o wygrane pieniężne lub rzeczowe, polegające na odgadywaniu wyników sportowego współzawodnictwa ludzi lub zwierząt (wyścigi konne), w których uczestnicy wpłacają stawki, a wysokość wygranej zależy od łącznej kwoty wpłaconych stawek. Zakłady bukmacherskie to zakłady o wygrane pieniężne lub rzeczowe, polegające na odgadywaniu zaistnienia różnych zdarzeń, w tym zdarzeń wirtualnych, w których uczestnicy wpłacają stawki, a wysokość wygranych zależy od umówionego, między przyjmującym zakład a wpłacającym stawkę, stosunku wpłaty do wygranej.

W ustawie z dnia 19 listopada 2009 r. o grach hazardowych definicja zakładów wzajemnych została zmodyfikowana poprzez dodanie zapisu, że są to zakłady o wygrane pieniężne, ale też rzeczowe. Jak wskazano w uzasadnieniu rządowego projektu ustawy o grach hazardowych, w dotychczas obowiązujących przepisach (tj. w uchylonej obecnie ustawie z dnia 29 lipca 1992 r. o grach i zakładach wzajemnych ${ }^{6}$ ) definicja wskazywała, że zakładami wzajemnymi są zakłady o wygrane pieniężne. Definicja ta okazała się niewystarczająca, czego skutkiem były próby organizowania takich zakładów o wygrane rzeczowe bez zezwolenia ${ }^{7}$. Aktualnie wspólnymi elementami obydwu typów zakładów wzajemnych są istnienie wygranej pieniężnej lub rzeczowej oraz element losowości polegający na odgadywaniu przyszłego zdarzenia ${ }^{8}$.

Nowelizacja ustawy o grach hazardowych dokonana ustawą z dnia 15 grudnia 2016 r. o zmianie ustawy o grach hazardowych oraz niektórych innych ustaw ${ }^{9}$ natomiast wprowadziła w obręb definicji zakładów wzajemnych pojęcie zdarzenia wirtualnego, przez które rozumie się generowane komputerowo zdarzenia dotyczące sportowego współzawodnictwa ludzi lub zwierząt (art. 2 ust. 2a u.g.h.).

\section{PROWADZENIE DZIAŁALNOŚCI W ZAKRESIE ZAKŁADÓW WZAJEMNYCH}

Działalność w zakresie zakładów wzajemnych może być prowadzona, stosownie do udzielonego zezwolenia, wyłącznie w punktach przyjmowania zakła-

6 T.j. Dz.U. 2004, poz. 27 z późn. zm.

7 Uzasadnienie rządowego projektu ustawy o grach hazardowych, Druk Sejmowy nr 2481, Warszawa 2009, s. 6.

8 M. Bik, R. Kamionowski, D. Obrępalski, K. Ryszard, Gry hazardowe. Komentarz do ustawy o grach hazardowych, Warszawa 2013, s. 16.

9 Dz.U. 2017, poz. 88. 
dów wzajemnych ${ }^{10}$ albo przez sieć Internet po uzyskaniu zezwolenia na urządzanie zakładów wzajemnych (art. 6 ust. 3 u.g.h.). Może odbywać się na zasadach i warunkach określonych w zatwierdzonym regulaminie i udzielonym zezwoleniu, a także wynikających z przepisów ustawy (art. 14 ust. 3 u.g.h.).

Zezwolenia na urządzanie zakładów wzajemnych udziela minister właściwy do spraw finansów publicznych (art. 32 ust. 2 u.g.h.). O zezwolenie mogą ubiegać się wyłącznie podmioty, które udokumentują legalność źródeł pochodzenia kapitału, niezaleganie z zapłatą podatków stanowiących dochód budżetu państwa oraz z zapłatą należności celnych oraz niezaleganie z zapłatą składek na ubezpieczenia społeczne oraz na ubezpieczenie zdrowotne (art. 34 ust. 1 u.g.h.). Ponadto o zezwolenie na prowadzenie działalności w zakresie zakładów wzajemnych mogą się ubiegać wyłącznie spółki, które udokumentują zgodność działania spółki z właściwymi przepisami regulującymi przeciwdziałanie praniu pieniędzy oraz finansowaniu terroryzmu, jak i dotyczącymi prowadzenia rachunkowości (art. 34a ust. 1 u.g.h.). Rozpatrzenie wniosków o udzielenie zezwolenia następuje w terminie 6 miesięcy od dnia złożenia wniosku (art. 40 ust. 1 u.g.h.). Jedno zezwolenie jest udzielane na prowadzenie określonej liczby punktów przyjmowania zakładów wzajemnych lub wykorzystywanie określonej liczby stron internetowych do urządzania zakładów wzajemnych (art. 41 ust. 3 u.g.h.).

Zezwolenie na urządzanie zakładów wzajemnych obejmuje:

1) nazwę spółki,

2) zatwierdzoną strukturę udziałów lub akcji imiennych, a także nazwiska członków zarządu i rady nadzorczej spółki,

3) miejsce urządzania i rodzaj zakładów wzajemnych wraz z określeniem, czy zakłady są urządzane przez sieć Internet, a w takim przypadku dodatkowo:

- adres strony internetowej wykorzystywanej do urządzania zakładów,

- zasady weryfikacji ukończenia 18. roku życia przez uczestników zakładów,

4) warunki, które powinna spełniać spółka,

5) nieprzekraczalny termin rozpoczęcia działalności. W przypadku prowadzenia działalności w zakresie zakładów wzajemnych termin ten dotyczy rozpoczęcia działalności we wszystkich punktach przyjmowania zakładów wzajemnych i na stronach internetowych, które zostały określone w zezwoleniu (art. 43 u.g.h.).

Podmiot posiadający zezwolenie może wystąpić o przedłużenie określonego w nich terminu rozpoczęcia działalności. Termin ten może zostać przedłużony jednokrotnie, na okres nie dłuższy niż 6 miesięcy. Podmiot posiadający zezwole-

${ }_{10}$ Przez punkt przyjmowania zakładów wzajemnych rozumie się wydzielone miejsce, w którym przyjmowane są zakłady totalizatora lub bukmacherstwa, na podstawie zatwierdzonego regulaminu (art. 4 ust. 1 pkt 2 u.g.h.). 
nie jest obowiązany w terminie 7 dni od dnia jego uzyskania poinformować organ właściwy w sprawie udzielenia zezwolenia o rozpoczęciu działalności objętej koncesją lub zezwoleniem, rezygnacji z działalności objętej koncesją lub zezwoleniem, przerwie w wykonywaniu działalności objętej koncesją lub zezwoleniem, wznowieniu działalności po przerwie (art. 49a u.g.h.). W przypadku nierozpoczęcia działalności w terminie określonym w zezwoleniu, zezwolenie wygasa w całości lub w części, w której nie podjęto działalności (art. 48 u.g.h.).

Wskazany wyżej podmiot jest obowiązany, w terminie określonym w zezwoleniu, złożyć, w celu zapewnienia ochrony interesu finansowego uczestników zakładów wzajemnych oraz zabezpieczenia zobowiązań podatkowych w podatku od gier, zabezpieczenie finansowe $\mathrm{w}$ wysokości 40 tys. zł w przypadku prowadzenia punktu przyjmowania zakładów wzajemnych. Ilość (krotność) zabezpieczeń zależy od liczby punktów przyjmowania zakładów wzajemnych. Przykładowo podmiot prowadzący od 1 do 3 punktów składa jedno zabezpieczenie, a podmiot prowadzący od 31 do 40 punktów - sześciokrotność zabezpieczenia. W przypadku urządzania zakładów wzajemnych przez sieć Internet, podmiot urządzający takie zakłady jest obowiązany złożyć, w terminie określonym w zezwoleniu, zabezpieczenie finansowe w wysokości 480 tys. zł (art. 63 ust. 1-2a u.g.h.). Dodatkowo podmiot urządzający zakłady wzajemne uiszcza opłatę za udzielenie lub zmianę zezwolenia (art. 68 ust. 1 pkt 1 i 4 u.g.h.). Opłata za udzielenie zezwolenia na urządzanie zakładów wzajemnych wynosi $2000 \%$ kwoty bazowej oraz dodatkowo:

- za każdy punkt przyjmowania zakładów wzajemnych: 50\% kwoty bazowej,

- za urządzanie zakładów wzajemnych przez sieć Internet: 2000\% kwoty bazowej,

- za każdą stronę internetową wykorzystywaną do urządzania zakładów wzajemnych: 5000\% kwoty bazowej (art. 69 ust. 1 pkt 1-3 u.g.h.).

Kwota bazowa dla danego roku kalendarzowego jest równa kwocie przeciętnego miesięcznego wynagrodzenia w sektorze przedsiębiorstw bez wypłat nagród z zysku, w drugim kwartale roku poprzedniego, ogłoszonego w obwieszczeniu Prezesa Głównego Urzędu Statystycznego w Dzienniku Urzędowym Głównego Urzędu Statystycznego (art. 70 u.g.h.).

Urządzanie zakładów wzajemnych stanowi również przedmiot opodatkowania podatkiem od gier. W przypadku podmiotów prowadzących działalność w zakresie zakładów wzajemnych obowiązek podatkowy powstaje z dniem rozpoczęcia urządzania gier w pierwszym punkcie lub na pierwszej stronie internetowej spośród punktów i stron objętych zezwoleniem. Podatnikiem jest osoba fizyczna, osoba prawna lub jednostka organizacyjna niemająca osobowości prawnej, która urządza zakłady wzajemne na podstawie udzielonego zezwolenia (art. 71 ust. 1, 2, 4 u.g.h.). Podstawę opodatkowania podatkiem od gier stanowi suma wpłaconych stawek (art. 73 ust. 1 pkt 4 u.g.h.). Stawka podatku od gier dla zakładów wzajemnych na sportowe współzawodnictwo zwierząt na podstawie zezwoleń 
udzielanych wyłącznie na ich urządzanie wynosi 2,5\%, a dla innych zakładów wzajemnych $12 \%$. Podatnicy są obowiązani, bez wezwania, do składania właściwemu naczelnikowi urzędu skarbowego deklaracji podatkowych dla podatku od gier, według ustalonego wzoru, a także do obliczania oraz wpłacania podatku od gier na rachunek właściwego urzędu skarbowego za okresy miesięczne, w terminie do 10. dnia miesiąca następującego po miesiącu, którego dotyczy rozliczenie (art. 75 ust. 1 u.g.h.).

\section{WYGRANA W ZAKŁADACH WZAJEMNYCH}

Wartość wygranej w grach hazardowych nie może być niższa od ceny losu lub innego dowodu udziału w grze albo kwoty wpłaconej stawki, przy czym w zakładach wzajemnych, w przypadku zakładów na odgadywanie zdarzeń wirtualnych, średnia zaprogramowana wartość wygranych nie może być niższa o więcej niż 5 punktów procentowych niż średnia wygrywalność w zakładach wzajemnych, w przypadku zakładów na odgadywanie zdarzeń niebędących zdarzeniami wirtualnymi za miesiąc poprzedzający. Podmiot urządzający zakłady wzajemne na odgadywanie zdarzeń wirtualnych archiwizuje dane na temat wyników zakładów. Dane te są przechowywane przez okres 5 lat, licząc od końca roku kalendarzowego, w którym dokonano ich archiwizacji. Po upływie tego okresu podmiot urządzający zakłady wzajemne na odgadywanie zdarzeń wirtualnych usuwa dane (art. 18 ust. 1,5 i 6 u.g.h.).

Wygrane w zakładach wzajemnych wypłaca się okazicielom dowodów udziału w tych grach lub za zwrotem tych dowodów, chyba że regulamin tych gier stanowi inaczej. Wypłata wygranej może nastąpić także na rzecz innej osoby niż wyżej wskazany okaziciel, jeżeli przedstawi on pełnomocnictwo z podpisem poświadczonym notarialnie udzielone przez taką osobę i w sposób określony w pełnomocnictwie, jeżeli jest zgodny z regulaminem gry. Pełnomocnictwo może obejmować również upoważnienie do odbioru zaświadczenia o uzyskanej wygranej. Możliwość odbioru wygranej przez przedstawiciela prawnego pozwala graczowi na nieujawnienie swojego wizerunku w przypadku uzyskania wysokiej wygranej ${ }^{11}$.

Podmiot urządzający zakłady wzajemne zgodnie z art. 19 ust. 3 u.g.h. może wstrzymać wypłatę wygranej na okres nieprzekraczający 30 dni, jeżeli zachodzą wątpliwości co do uprawnień okaziciela do rozporządzania dowodem udziału w grze. Można zadać pytanie: Co w przypadku, gdy 30 dni okaże się za mało, aby rozwiać wątpliwości? Jeżeli przyjmiemy, że art. 19 ust. 3 u.g.h. jest przepisem szczególnym do art. $921^{11} \S 1$ ustawy z dnia 23 kwietnia 1964 r. - Kodeks

${ }^{11}$ Uzasadnienie rządowego projektu ustawy o grach hazardowych, s. 13. 
cywilny ${ }^{12}$, to $\mathrm{w}$ takim przypadku podmiot urządzający gry hazardowe zobowiązany jest złożyć przedmiot świadczenia (wygraną) do depozytu sądowego. W przypadku nieuzasadnionego wstrzymania wypłaty (wydania) wygranej podmiot urządzający taką grę jest obowiązany zapłacić odsetki ustawowe za okres wstrzymania wypłaty (wydania) ${ }^{13}$. Nie dokonuje się wypłaty wygranej na podstawie dowodu udziału w zakładzie wzajemnym, jeżeli nie można stwierdzić jego autentyczności lub ustalić jego numeru. W razie utraty dowodu udziału w zakładzie wzajemnym, stwierdzającego udział w takiej grze, uczestnikowi gry nie przysługują żadne roszczenia wobec podmiotu urządzającego grę, chyba że regulamin gry stanowi inaczej.

Podmiot urządzający zakłady wzajemne jest obowiązany, na żądanie uczestnika takiej gry, wystawić imienne zaświadczenie o uzyskanej przez niego wygranej. Zaświadczenie jest drukiem ścisłego zarachowania. Zaświadczenie może być wystawione najpóźniej w dniu następującym po dniu, w którym uzyskano wygraną, lub po dniu, w którym nastąpiła wypłata wygranej (art. 20 ust. 1-2 u.g.h.).

Wysokość wygranej albo przegranej w zakładzie wzajemnym stanowi tajemnicę jej uczestnika, której jest obowiązany przestrzegać podmiot urządzający tę grę (art. 20 ust. 8 u.g.h.). Informacje o wysokości wygranej albo przegranej są ujawniane wyłącznie na żądanie Generalnego Inspektora Informacji Finansowej, organów Krajowej Administracji Skarbowej, funkcjonariusza Służby Celno-Skarbowej i Policji, a także sądu i prokuratora w związku z toczącym się postępowaniem. Informacje o wysokości wygranej albo przegranej są ujawniane również na żądanie Szefa Agencji Bezpieczeństwa Wewnętrznego w ramach prowadzonego postępowania sprawdzającego, o którym mowa w ustawie $\mathrm{z}$ dnia 5 sierpnia 2010 r. o ochronie informacji niejawnych ${ }^{14}$.

Roszczenia związane $\mathrm{z}$ udziałem w zakładzie wzajemnym przedawniają się z upływem 6 miesięcy od dnia wymagalności. Bieg przedawnienia roszczeń ulega zawieszeniu na okres od dnia wniesienia reklamacji do dnia udzielenia odpowiedzi na reklamację (art. 21 ust. 1-2 u.g.h.).

Podmiot prowadzący działalność w zakresie zakładów wzajemnych jest obowiązany zapewnić utrzymanie porządku i ładu w punkcie przyjmowania zakładów wzajemnych. Podmiot urządzający gry hazardowe jest obowiązany zapoznać uczestników gier przed przystąpieniem do gry z zasadami gry i możliwościami wyboru wariantów zakładu wzajemnego oraz z innymi, wymienionymi w regula-

12 T.j. 2018, poz. 1025 z późn. zm., dalej: k.c. Zgodnie z art. $921^{11} \S 1$ k.c. dłużnik powinien złożyć przedmiot świadczenia do depozytu sądowego, jeżeli istnieją wątpliwości, czy okaziciel dokumentu jest wierzycielem.

${ }^{13}$ G. Skowronek, Charakter prawny dokumentu potwierdzajacego udziat w grze hazardowej, [w:] Ewolucja instytucji polskiego prawa papierów wartościowych. W 80-lecie Prawa wekslowego $z$ dnia 28 kwietnia 1936 r., red. J. Mojak, J. Widło, A. Żywicka, Lublin 2016, s. 26-27.

14 T.j. Dz.U. 2018, poz. 412 z późn. zm. 
minie, zastrzeżeniami dotyczącymi sposobu gry. Podmiot urządzający gry hazardowe utrzymuje urządzenia do zakładów wzajemnych w stanie gwarantującym grę zgodną z regulaminem, a uczestnikom gry zapewnia bezpieczne korzystanie z nich. Podmiot prowadzący działalność w zakresie zakładów wzajemnych w celu ochrony interesu uczestników tych gier i osób trzecich może odmówić wstępu albo usunąć z punktu przyjmowania zakładów wzajemnych osobę, która nie przestrzega postanowień regulaminu zakładu wzajemnego.

\section{OGRANICZENIA W URZĄDZANIU ZAKŁADÓW WZAJEMNYCH}

W celu zwiększenia ochrony społeczeństwa i praworządności przed negatywnymi skutkami hazardu funkcjonują w ustawie o grach hazardowych ograniczenia w urządzaniu zakładów wzajemnych przez podmioty prowadzące działalność w zakresie tych gier. Przyjmuje się, że takie ograniczenia są prawnym instrumentem polityki publicznej, stanowiącym ochronę dla gracza przed uzależnieniem.

W szczególności wstęp do punktów przyjmowania zakładów wzajemnych dozwolony jest dla osób, które ukończyły 18 lat. W zakładach wzajemnych mogą uczestniczyć wyłącznie osoby, które ukończyły 18 lat. Podmioty urządzające zakłady wzajemne i prowadzące działalność w tym zakresie są obowiązane do umieszczenia w widoczny sposób przed wejściem do miejsca ich urządzania oraz w miejscu urządzania zakładów wzajemnych lub sprzedaży dowodów udziału w tych grach informacji o zakazie uczestniczenia w grach osób, które nie ukończyły 18. roku życia. W przypadku wątpliwości co do wieku uczestnika zakładów wzajemnych, osoba przyjmująca zakłady wzajemne jest upoważniona do żądania okazania dokumentu potwierdzającego tożsamość i wiek uczestnika tej gry hazardowej (art. 27 ust. 1-4 u.g.h.).

Przepis art. 29 ust. 1 u.g.h. wprowadza zakaz reklamy i promocji zakładów wzajemnych. Efektem tej regulacji jest penalizacja w przepisach ustawy z dnia 10 września 1999 r. - Kodeks karny skarbowy ${ }^{15}$ zakazanych form zachęcania do udziału w zakładach wzajemnych ${ }^{16}$. Nie jest to jednak zakaz bezwzględny, wyjątek od niego wprowadzają bowiem art. 29 ust. 5 i art. 29 b u.g.h. Zakaz określony w art. 29 ust. 1 nie obejmuje reklamy i promocji prowadzonej wewnątrz punktu przyjmowania zakładów wzajemnych oraz oznaczenia nazwą podmiotu, logo firmy lub nazwą prowadzonej działalności gospodarczej na zewnątrz budynku, miejsca, w którym znajduje się punkt przyjmowania zakładów wzajemnych, a także - w przypadku zakładów wzajemnych urządzanych przez sieć Internet reklamy i promocji prowadzonej na określonej w zezwoleniu stronie internetowej

15 T.j. 2018, poz. 1958 z późn. zm.

${ }^{16}$ G. Skowronek, Analiza pojęć , reklama” i „promocja” gier hazardowych, „Ruch Prawniczy, Ekonomiczny i Socjologiczny” 2015, nr 4, s. 147-148. 
wykorzystywanej do urządzania tych zakładów. Natomiast przepis art. 29b ust. 1 u.g.h. stanowi, że dozwolona jest reklama zakładów wzajemnych, na urządzanie których zostało udzielone zezwolenie. Taka liberalizacja przepisów odnoszących się do ograniczeń reklamy zakładów wzajemnych, na urządzanie których zostało udzielone zezwolenie, wiąże się jednocześnie z określeniem katalogu przedmiotowo-podmiotowego warunków, które muszą być spełnione, aby reklama zakładów wzajemnych była prawnie dozwolona. Reklama taka jest zatem możliwa, jeżeli:

1) nie jest kierowana do małoletnich, nie przedstawia osób małoletnich i nie odbywa się przy udziale małoletnich,

2) nie łączy urządzania gier lub uczestniczenia w grach ze sprawnością fizyczną, intelektualną bądź szansą na uzyskanie łatwej wygranej,

3) nie zawiera stwierdzeń, że udział w grach hazardowych ma relaksujący, uspokajający skutek lub jest sposobem rozwiązywania konfliktów osobistych lub problemów finansowych,

4) nie przedstawia powstrzymywania się lub umiarkowanego uczestniczenia w grach w negatywny sposób,

5) nie zachęca do uiszczania wyższych stawek jako czynnika zwiększającego szansę na wygraną,

6) nie wywołuje skojarzeń z:

- atrakcyjnością seksualną,

- relaksem lub wypoczynkiem,

- nauką lub pracą,

- sukcesem zawodowym, życiowym lub finansowym (art. 29 b ust. 1 u.g.h.).

Równolegle zostały wprowadzone zakazy reklamy zakładów wzajemnych, która nie może być prowadzona:

1) w telewizji, radiu, kinie i teatrze między godziną 6.00 a 22.00 , z wyłączeniem reklamy prowadzonej $\mathrm{w}$ trakcie transmisji z imprez sportowych, których podmiot prowadzący działalność w zakresie przyjmowania zakładów wzajemnych jest sponsorem lub jest sponsorem drużyny lub zawodników biorących czynny udział w danej imprezie sportowej,

2) w prasie młodzieżowej i dziecięcej,

3) na okładkach dzienników i czasopism,

4) w miejscach publicznych, z wyłączeniem imprez masowych i imprez sportowych, których podmiot prowadzący działalność w zakresie przyjmowania zakładów wzajemnych jest sponsorem lub jest sponsorem drużyny lub zawodników biorących czynny udział w danej imprezie sportowej, lub jest sponsorem związku sportowego, który ma związek z organizowaną imprezą. Wyłączenie, o którym mowa powyżej, obejmuje tylko reklamy gier organizowanych przez sponsora lub reklamę sponsora. Reklama taka może być prowadzona pod warunkiem umieszczenia w niej komunikatu o konsekwencjach udziału w nielegalnych grach hazardowych, ryzyku 
związanym z hazardem oraz posiadaniu zezwolenia na urządzanie zakładów wzajemnych (art. $29 \mathrm{~b}$ ust. 2-3 u.g.h.).

\section{ORGANIZACJA ZAKŁADÓW WZAJEMNYCH NA TLE ORZECZNICTWA TRYBUNAŁU SPRAWIEDLIWOŚCI UNII EUROPEJSKIEJ}

Pierwszym z serii orzeczeń wydanych przez TSUE, a poświęconych hazardowi, które zarazem było początkiem dyskusji w Unii Europejskiej nad zagadnieniem hazardu, jest rozstrzygnięcie w sprawie Schindler ${ }^{17}$. W przedmiotowej sprawie bracia Schindler, działający w Niemczech jako koncesjonowani dostawcy usług hazardowych, podjęli działania polegające na kierowaniu do obywateli Wielkiej Brytanii przesyłek zawierających zaproszenie do udziału w organizowanej przez nich loterii wraz z kuponem zgłoszeniowym i kopertą zwrotną. Przesyłki zostały przejęte i skonfiskowane przez brytyjski Królewski Urząd Cła i Akcyzy (Her Majesty's Customs and Excise), natomiast przeciwko braciom zostało przed sądem brytyjskim wszczęte postępowanie w sprawie o wykroczenie przeciwko zakazowi organizowania na obszarze Zjednoczonego Królestwa loterii na dużą skalę, w świetle prawa brytyjskiego niedozwolonych ${ }^{18}$.

TSUE, zajmując się tą sprawą, poddał analizie brytyjskie regulacje prawne, zgodnie z którymi zakazane jest, za wyjątkiem sytuacji, które to prawo samo określa, przeprowadzanie loterii na terytorium państwa członkowskiego. TSUE uznał, iż stanowią one ograniczenie swobodnego przepływu usług, w tym przypadku usług hazardowych, z tym że te ograniczenia nie mają charakteru dyskryminującego ${ }^{19}$. Co istotne, TSUE zakwalifikował organizowanie i prowadzenie gier, w tym także zakładów wzajemnych, jako świadczenie usług. Tym samym legalny hazard przy takim założeniu co do zasady winien korzystać ze swobody przepływu usług w rozumieniu art. 56 Traktatu o funkcjonowaniu Unii Europejskiej $^{20}$. Jednocześnie TSUE zauważył, że przedmiotowe regulacje prawne zmierzają do ochrony osób korzystających z tego rodzaju usług (konsumentów), jak również porządku społecznego. Powyższe okoliczności są podstawą na gruncie

17 Wyrok z dnia 24 marca 1994 r. Her Majesty's Customs and Excise przeciwko Gerhart Schindler i Jörg Schindler, C-275/92, LexPolonica nr 388442.

18 Wielka Brytania w regulacjach określających zasady gry w całości wykluczyła podmioty z innych państw członkowskich odnośnie do promowania swoich loterii i sprzedawania biletów na rynku Zjednoczonego Królestwa. Podaję za: Analiza usług w zakresie gier hazardowych na rynku wewnętrznym Unii Europejskiej przygotowana na potrzeby Komisji Europejskiej przez Szwajcarski Instytut Prawa Porównawczego (Swiss Institute of Comparative Law - SICL), Badanie sytuacji prawnej (Legal study), Lozanna, 14 czerwca 2006, s. 972.

19 G. Skowronek, Prawne aspekty hazardu, Wrocław 2012, s. 104-106.

${ }^{20}$ Traktat o funkcjonowaniu Unii Europejskiej, wersja skonsolidowana Traktatu o Unii Europejskiej i Traktatu o funkcjonowaniu Unii Europejskiej z dnia 30 marca 2010 r. uwzględniająca zmiany wprowadzone Traktatem lizbońskim (Dz.Urz. UE C 83/01), dalej: TFUE. 
prawa Unii Europejskiej do stanowienia przez państwa członkowskie przeszkód w swobodnym przepływie m.in. usług. TSUE, analizując przesłanki, jakie mogą usprawiedliwiać nałożenie przez państwo ograniczeń na usługi hazardowe, zwrócił uwagę, że:

Po pierwsze, nie należy lekceważyć moralnych, religijnych i kulturowych walorów loterii i innych rodzajów hazardu, jakie są im przypisywane we wszystkich państwach członkowskich. Generalną tendencją w państwach członkowskich jest bowiem stanowienie ograniczeń lub nawet zakazów prowadzenia działalności hazardowej i zapobieganie uczynienia z niej źródła zysków dla osób prywatnych. Po drugie, loteriom towarzyszy zwiększone ryzyko wystąpienia działań przestępczych, wziąwszy pod uwagę wielkości obstawianych sum i wypłacanych wygranych, w szczególności gdy ma się do czynienia z działalnością prowadzoną na dużą skalę. Po trzecie, istnienie loterii stanowi zachętę do wydatkowania pieniędzy, co może nieść negatywne skutki zarówno dla jednostek, jak i ogółu społeczeństwa ${ }^{21}$.

Zakazy są zatem uzasadnione z uwagi na ochronę moralnych, religijnych i kulturowych norm, zapobieganie prywatnemu zyskowi pochodzącemu ze świadczenia usług hazardowych, zapobieganie oszustwom i innemu rodzajowi działalności przestępczej z uwagi na wielkość kwot, które mogą być stawiane i ewentualnie wygrywane, oraz zapobieganie zachęcaniu do nadmiernych wydatków na usługi hazardowe, biorąc pod uwagę możliwe problemy wynikające ze szkód dla osób fizycznych i całego społeczeństwa.

Z kolei w sprawie Zenatti ${ }^{22}$ stan faktyczny był następujący - działający we Włoszech bukmacher pośredniczył w przyjmowaniu przez swojego brytyjskiego odpowiednika zakładów sportowych od włoskich graczy, która to działalność powinna być, zgodnie z włoskim prawem, nadzorowana przez określone w ustawie krajowe stowarzyszenia ${ }^{23}$ wykonujące zadania zlecone przez władze publiczne ${ }^{24}$.

TSUE, powołując się m.in. na sprawę Schindler, potwierdził, że włoskie prawo krajowe jest prawidłowe. Stwierdził też, że postanowienia TFUE nie stoją na przeszkodzie ustawodawstwu krajowemu, takiemu jak ustawodawstwo włoskie, które zastrzega dla niektórych podmiotów prawo do zawierania zakładów na zawody sportowe, jeśli ustawodawstwo to jest rzeczywiście uzasadnione przez

${ }^{21}$ Wyrok z dnia 24 marca 1994 r. Her Majesty's Customs and Excise przeciwko Gerhart Schindler i Jörg Schindler, C-275/92, pkt 57-58 i 60.

22 Wyrok z dnia 21 października 1999 r. Questore di Verona przeciwko Diego Zenatti, C-67/98, LexPolonica $\mathrm{nr} 376551$.

${ }^{23}$ Comitato Olimpico Nazionale Italiano (CONI - Włoski Narodowy Komitet Olimpijski) lub też (dla wyścigów konnych) Unione nazionale per I'incremento delle razze equine (UNIRE - Krajowy Związek na Rzecz Doskonalenia Ras Koni).

${ }^{24}$ Przepisy ustawodawstwa włoskiego w przypadku ujętym w orzeczeniu nie zakazują całkowicie zawierania zakładów, ale zastrzegają prawo do organizowania w pewnych okolicznościach zakładów wzajemnych dla niektórych jednostek. Podaję za: Analiza usług w zakresie gier hazardowych na rynku wewnętrznym Unii Europejskiej..., s. 974. 
cele polityki społecznej zmierzające do ograniczenia niekorzystnych skutków takich działalności i jeśli ograniczenia, które obowiązują, nie są nieproporcjonalne w świetle tych celów. Celami są natomiast m.in. zapobieganie grom stanowiącym źródło zysków prywatnych oraz unikanie ryzyka przestępstw i oszustw.

Zarazem TSUE wyraźnie zaznaczył, że zakres ochrony, którą państwo członkowskie ma zamiar świadczyć (całkowite lub częściowe zakazy, ograniczenia, kontrola procedur), należy do swobodnego uznania władz w kontekście realizowanego celu, a sam fakt, że państwo członkowskie wybrało odmienny system ochrony niż przyjęty przez inne państwo członkowskie, nie może wpływać na ocenę konieczności proporcjonalności przyjętych przepisów. Ponadto fakt, że gry nie są całkowicie zakazane, nie jest wystarczającym dowodem na to, że krajowe ustawodawstwo nie jest w rzeczywistości przeznaczone do osiągania celów interesu publicznego, do których dąży i które muszą być traktowane jako całość. Ograniczone zezwolenie do uprawiania hazardu przypisane do niektórych organów ma tę zaletę, że ogranicza chęć hazardu i koncentruje gry w kontrolowanych kanałach oraz zapobiega ryzyku nadużyć i przestępczości w kontekście eksploatacji i wykorzystania zysków dla celów interesu publicznego, również wchodzącego w zakres tych celów. Ograniczenie takie jest dopuszczalne jedynie wówczas, gdy celem jest doprowadzenie do prawdziwego zmniejszenia okazji do gry, jeśli finansowanie społeczne poprzez pobieranie opłat od wpływów upoważnionego do gry stanowi jedyny korzystny skutek, a nie rzeczywiste uzasadnienie przyjętej polityki.

TSUE wskazał zatem, że włoski model rynku gier może być uznany za poprawny z punktu widzenia potrzeby zagwarantowania swobody przepływu usług, jeżeli w swej istocie stanowi wyraz dążenia ustawodawcy do generalnego zmniejszenia okazji do oddawania się grze oraz jeżeli finansowanie z przychodów czerpanych z gier działań o charakterze społecznym jest korzystnym skutkiem ubocznym, a nie faktycznym powodem przyjęcia restrykcyjnych uregulowań ${ }^{25}$.

Ujęte w powyższych orzeczeniach tezy przeniesione na grunt polskiej ustawy o grach hazardowych niewątpliwie uzasadniają reglamentację dotyczącą uczestniczenia w zakładach wzajemnych wyłącznie osób, które ukończyły 18 lat, czy też ograniczenia w zakresie reklamy. Są one tylko potwierdzeniem akceptowalnych w Unii Europejskiej standardów co do tego, że można podejmować działania w kierunku zapobiegania czynienia z działalności hazardowej źródła zysków dla osób prywatnych. Poza tym niekontrolowanemu rozwojowi gier, na co może mieć wpływ reklama, towarzyszy zwiększone ryzyko uzależnienia i wystąpienia działań niezgodnych z prawem. Powszechnie też się przyjmuje, że dzieci i młodzież przed ukończeniem 18. roku życia to grupy szczególnie narażone na uzależnienie

${ }^{25}$ G. Skowronek, Prawne aspekty..., s. 109-110. 
od gier ${ }^{26}$. Wnioski takie należy wyciągnąć $\mathrm{z}$ badań przeprowadzonych na gruncie psychologicznym, z których wynika, że problem z hazardem patologicznym występuje u dzieci, zwłaszcza dorastających, i jest znacznie większy, gdy wzorują się na grających rodzicach ${ }^{27}$.

\section{PODSUMOWANIE}

Problematyka dotycząca gier hazardowych niezmiennie stanowi obszar wymagający zainteresowania przedstawicieli nauki prawa. Przedstawione rozważania odnosiły się do analizy regulacji dotyczących urządzania zakładów wzajemnych. Zmierzały one bezpośrednio do udzielenia odpowiedzi na pytanie, czy obowiązujący model prowadzenia działalności w zakresie zakładów wzajemnych odpowiada kryteriom współczesnych kierunków kontroli państwowej i polityki finansowej. Ponadto istotne było określenie, czy polskie regulacje są zgodne z podstawowymi zasadami wyznaczanymi przez prawodawstwo Unii Europejskiej.

Niewątpliwie hazard jest sferą niezwykle dochodowych stosunków społeczno-gospodarczych. W tych okolicznościach rozwiązania prawa hazardowego mają na celu zwiększenie efektywności i skuteczności kontroli, zwiększenie pewności podmiotów legalnie prowadzących działalność oraz uporządkowanie systemu podatkowego w zakresie podatku od gier. Niezwykle istotne jest także zwiększenie ochrony społeczeństwa i praworządności przed negatywnymi skutkami uprawiania zakładów wzajemnych. Przecież nawet w orzecznictwie TSUE wyraźnie widać przestrogę, aby nie lekceważyć moralnych, religijnych i kulturowych walorów loterii i innych rodzajów hazardu, jakie są im przypisywane we wszystkich państwach członkowskich. Uregulowanie w tym zakresie stanowi część dziedziny, w której między państwami członkowskimi istnieją rozbieżności dotyczące wartości moralnych, religijnych i kulturalnych. Generalną i dopuszczalną tendencją w państwach członkowskich jest więc stanowienie ograniczeń lub nawet zakazów prowadzenia działalności hazardowej oraz zapobieganie uczynieniu z niej źródła zysków dla osób prywatnych.

Powyższe rozważania wskazują na istnienie w prawie polskim precyzyjnych zasad prowadzenia działalności w zakresie zakładów wzajemnych oraz potwierdzają, że w prawie polskim istnieją akceptowalne z punktu widzenia regulacji Unii Europejskiej ograniczenia w urządzaniu tych gier hazardowych.

${ }^{26}$ Idem, Konsekwencje prawne umożliwienia udziatu $w$ grze hazardowej osobie, która nie ukończyta 18. roku życia, [w:] Na styku prawa karnego i prawa o wykroczeniach. Zagadnienia materialnoprawne oraz procesowe. Księga jubileuszowa dedykowana Profesorowi Markowi Bojarskiemu, red. J. Sawicki, K. Łucarz, Wrocław 2016, s. 484-493.

27 M. Griffiths, Gry i hazard. Uzależnienia dzieci w okresie dorastania, Gdańsk 2004, s. 38. 


\section{BIBLIOGRAFIA}

\section{LITERATURA}

Analiza usług w zakresie gier hazardowych na rynku wewnętrznym Unii Europejskiej przygotowana na potrzeby Komisji Europejskiej przez Szwajcarski Instytut Prawa Porównawczego (Swiss Institute of Comparative Law - SICL), Badanie sytuacji prawnej (Legal study), Lozanna, 14 czerwca 2006.

Bik M., Kamionowski R., Obrępalski D., Ryszard K., Gry hazardowe. Komentarz do ustawy o grach hazardowych, Warszawa 2013.

Bojarski M., Glosa do uchwaty SN z 16 lutego 1994 r., I KZP 39/94, „Wojskowy Przegląd Prawniczy" 1994, nr 3-4.

Bojarski M., Radecki W., Kodeks wykroczeń. Komentarz, Warszawa 1998.

Dzik B., Hazard, [w:] Psychologia ekonomiczna, red. T. Tyszka, Gdańsk 2004.

Griffiths M., Gry i hazard. Uzależnienia dzieci w okresie dorastania, Gdańsk 2004.

Niewiadomska I., Brzezińska M., Lelonek B., Hazard, Lublin 2005.

Skowronek G., Analiza pojęć „reklama” $i$ „promocja” gier hazardowych, „Ruch Prawniczy, Ekonomiczny i Socjologiczny" 2015, nr 4.

Skowronek G., Charakter prawny dokumentu potwierdzajacego udziat w grze hazardowej, [w:] Ewolucja instytucji polskiego prawa papierów wartościowych. W 80-lecie Prawa wekslowego $z$ dnia 28 kwietnia 1936 r., red. J. Mojak, J. Widło, A. Żywicka, Lublin 2016.

Skowronek G., Konsekwencje prawne umożliwienia udziatu w grze hazardowej osobie, która nie ukończyła 18. roku życia, [w:] Na styku prawa karnego i prawa o wykroczeniach. Zagadnienia materialnoprawne oraz procesowe. Ksiega jubileuszowa dedykowana Profesorowi Markowi Bojarskiemu, red. J. Sawicki, K. Łucarz, Wrocław 2016.

Skowronek G., Prawne aspekty hazardu, Wrocław 2012.

Stownik języka polskiego, red. M. Szymczak, t. 1, Warszawa 1982.

Uzasadnienie rzadowego projektu ustawy o grach hazardowych, Druk Sejmowy nr 2481, Warszawa 2009.

\section{AkTy PRAWNe}

Traktat o funkcjonowaniu Unii Europejskiej, wersja skonsolidowana Traktatu o Unii Europejskiej i Traktatu o funkcjonowaniu Unii Europejskiej z dnia 30 marca 2010 r. uwzględniająca zmiany wprowadzone Traktatem lizbońskim (Dz.Urz. UE C 83/01).

Ustawa z dnia 23 kwietnia 1964 r. - Kodeks cywilny (t.j. 2018, poz. 1025 z późn. zm.).

Ustawa z dnia 29 lipca 1992 r. o grach i zakładach wzajemnych (t.j. Dz.U. 2004, poz. 27 z późn. zm.). Ustawa z dnia 10 września 1999 r. - Kodeks karny skarbowy (t.j. 2018, poz. 1958 z późn. zm.).

Ustawa z dnia 19 listopada 2009 r. o grach hazardowych (t.j. Dz.U. 2018, poz. 165 ze zm.).

Ustawa z dnia 5 sierpnia 2010 r. o ochronie informacji niejawnych (t.j. Dz.U. 2018, poz. 412 z późn. zm.). Ustawa z dnia 15 grudnia 2016 r. o zmianie ustawy o grach hazardowych oraz niektórych innych ustaw (Dz.U. 2017, poz. 88).

\section{Orzecznictwo}

Wyrok z dnia 24 marca 1994 r. Her Majesty's Customs and Excise przeciwko Gerhart Schindler i Jörg Schindler, C-275/92, LexPolonica nr 388442.

Wyrok z dnia 21 października 1999 r. Questore di Verona przeciwko Diego Zenatti, C-67/98, LexPolonica nr 376551. 


\section{SUMMARY}

This study was devoted to the analysis of the conditions for the organization of mutual bets, regulations on the basis of which the activity in this area is carried out and the rules of their taxation with gambling tax. Undoubtedly mutual betting, being a type of gambling must be subject to strict regulations and in some cases restrictions. The reason for these restrictions is the fact that gambling brings threats, in particular, addiction to games. The answer to the danger of addiction is the introduction of a number of barriers and financial restrictions for the activities related to the organization of mutual bets. At the same time, one should be aware that the introduction of regulation of any sphere of economic activity must be in accordance with European Union regulations regarding freedoms, e.g. in the area of the flow of services. Therefore, it is important to analyze the financial aspects related to mutual betting and to assess it from the point of view of the jurisprudence of the Court of Justice of the European Union.

Keywords: gambling; mutual bets; games; advertising; case law of the Court of Justice of the European Union

\section{STRESZCZENIE}

Niniejsze opracowanie zostało poświęcone analizie warunków urządzania zakładów wzajemnych - regulacji, na podstawie których prowadzona jest działalność w tym zakresie oraz zasad ich opodatkowania podatkiem od gier hazardowych. Niewątpliwie zakłady wzajemne, stanowiąc rodzaj hazardu, muszą podlegać ścisłym regulacjom oraz - w niektórych przypadkach - ograniczeniom. Powodem tych ograniczeń jest fakt, że hazard niesie za sobą zagrożenia, w tym w szczególności uzależnienie od gier. Odpowiedzią na niebezpieczeństwo uzależnienia jest wprowadzanie szeregu barier i restrykcji finansowych dla działalności związanej z organizowaniem zakładów wzajemnych. Jednocześnie należy mieć świadomość, że wprowadzenie reglamentacji jakiejkolwiek sfery działalności gospodarczej musi pozostawać w zgodzie z regulacjami Unii Europejskiej dotyczącymi swobód np. w zakresie przepływu usług. Istotna jest zatem analiza finansowych aspektów związanych z zakładami wzajemnymi oraz poddanie jej ocenie z punktu widzenia orzecznictwa Trybunału Sprawiedliwości Unii Europejskiej.

Słowa kluczowe: hazard; zakłady wzajemne; gry; reklama; orzecznictwo Trybunału Sprawiedliwości Unii Europejskiej 